Portland State University

PDXScholar

1-30-1995

\title{
The Effects of Positive Illusions on Perceived Racism
}

Miyako Jun-ko Hayashi

Portland State University

Follow this and additional works at: https://pdxscholar.library.pdx.edu/open_access_etds

Part of the Psychology Commons

Let us know how access to this document benefits you.

\section{Recommended Citation}

Hayashi, Miyako Jun-ko, "The Effects of Positive Illusions on Perceived Racism" (1995). Dissertations and Theses. Paper 5088.

https://doi.org/10.15760/etd.6964

This Thesis is brought to you for free and open access. It has been accepted for inclusion in Dissertations and Theses by an authorized administrator of PDXScholar. Please contact us if we can make this document more accessible: pdxscholar@pdx.edu. 


\section{Thesis Approval}

The abstract and thesis of Miyako Jun-ko Hayashi for the Master of Science in Psychology presented January 30, 1995, and accepted by the thesis committee and the department.

Committee Approvals:
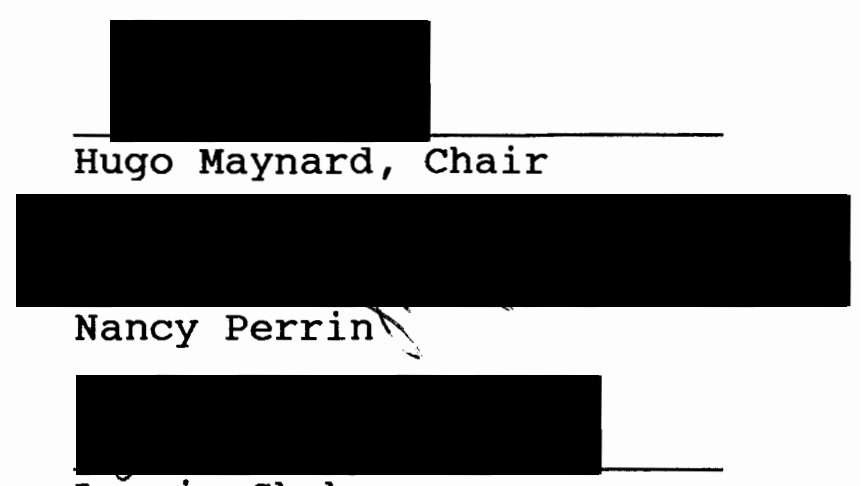

Laurie Skokan

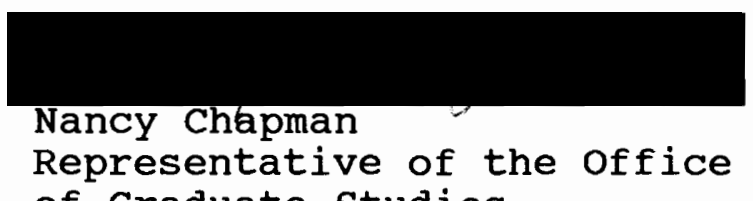

Department Approval:
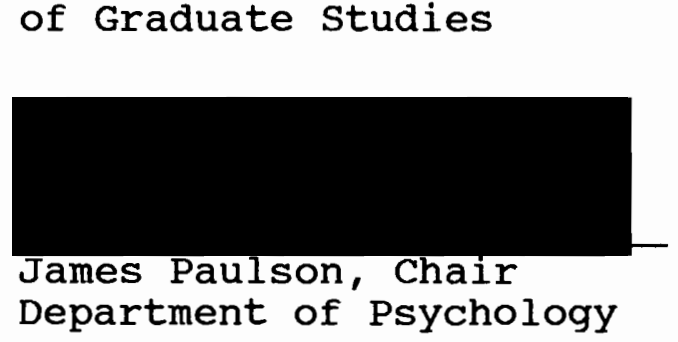

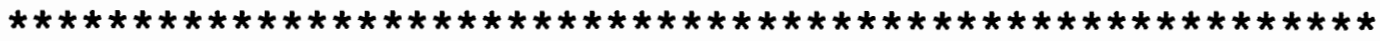

Accepted for Portland State University by the Library

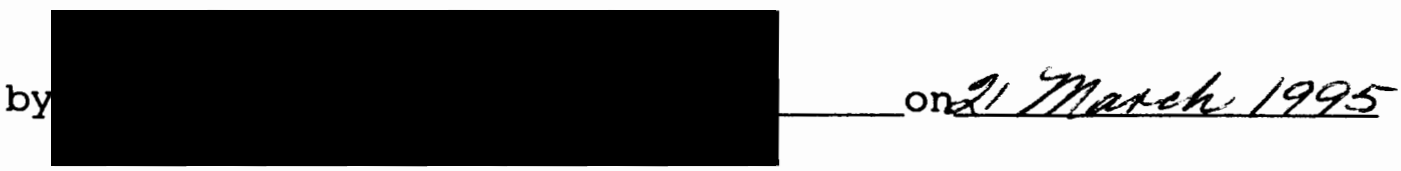


Abstract

An abstract of the thesis of Miyako Jun-ko Hayashi for the Master of Science in Psychology, presented January 30,1995

Title: The Effects of Positive Illusions on Perceived Racism .

This study investigated the effects of selfesteem, controllability, and optimism, the constructs inherent in positive illusions, on perceived racism. The perceived racism scale in this study was found to contain two dimensions, Equal Opportunity (EO) racism and Authority (AUT) racism. Thirty-seven AfricanAmerican, 64 Asian-American and 100 White-American students at Portland States University (101 females, 100 males and mean age of 25 years) served as subjects. The findings revealed that both African- and AsianAmerican students perceived a racist atmosphere from peer students (EO racism) significantly higher than did the White-American students. However, only AfricanAmerican students perceived greater racism from faculty members (AUT racism) than the White-American students. None of the illusions had an effect on perceived EO 
racism. However, all types of illusions (self-esteem, controllability and optimism) had a significant effect on perceived racism from faculty members (AUT racism). Higher perception of AUT racism was correlated with less self-esteem $(\underline{\underline{r}}=-.089, \underline{\underline{p}}=.12)$, less controllability $(\underline{\underline{r}}=-.319, \underline{p}<.001)$, and less optimism $(\underline{r}=-.144, \underline{p}=.03)$. The results of this study support empirical evidence showing that the illusions, especially controllability, change individuals in how they perceive racism when the racism is practiced by authorities. 
The Effects of Positive Illusions on Perceived Racism

\author{
by \\ Miyako Jun-ko Hayashi
}

A thesis submitted in partial fulfillment of the requirements for the degree of

\author{
MASTER OF SCIENCE \\ in \\ PSYCHOLOGY
}

Portland State University

1995 
Acknowledgements

This thesis is dedicated to my sons, Andrew and Wesley Bliesner. Their smiles have always been a source of motivation.

I am greatly indebted to Yaeko steidel, my spiritual mother, for her genuine guidance during the hardship.

I also thank David Bliesner, for his long-time patience.

My sincere appreciation goes to Dr. Hugo Maynard, Dr. Nancy Perrin and Dr. Laurie Skokan. Without their support, this thesis would not have come to completion. Thank you all very much. 
Table of Contents

Page

List of Tables..................... iv

The effects of positive illusions

on perceived racism.................. 1

Race and racism................... 4

Positive illusions and personal health.......7

Hypotheses.......................11

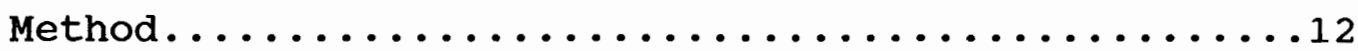

Subjects.........................

Procedure..........................13

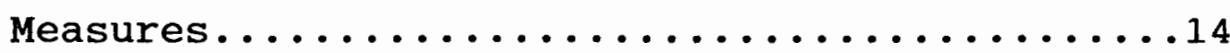

Results...........................

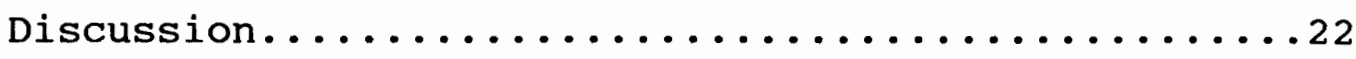

References............................ 7

Appendices

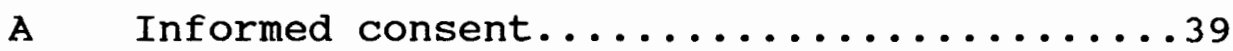

B Questionnaire...................40 
List of Tables

Table

Page

1 Demographic information..................... 33

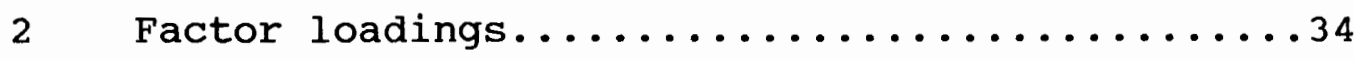

3 Mean scores and standard deviation for EO

and AUT racism for each racial group.....35

4 Hierarchical MLR: the effect of self-esteem

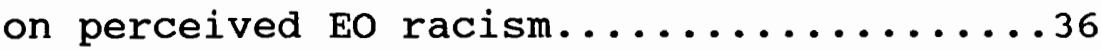

5 Hierarchical MLR: the effect of self-esteem

on perceived AUT racism...................

6 Hierarchical MLR: the effect of

controllability on perceived EO racism...37

7 Hierarchical MLR: the effect of

controllability on perceived AUT racism...37

8 Hierarchical MLR: the effect of optimism

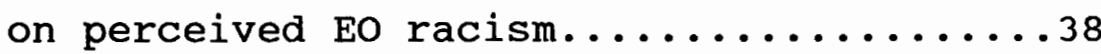

9 Hierarchical MLR: the effect of optimism

on perceived AUT racism.............38 
Perceived Racism

The Effects of Positive Illusions on

Perceived Racism

The United States has had racial problems from its beginnings (Bennett, 1962). In the last several decades, legal improvements have been made to insure equal rights and opportunities for people of color. Although improvements have been made, there is still significant tension between racial groups. Hate crimes, riots, and law suits caused by poor racerelations are often reported by the media. Research has shown that racial segregation in the United States has not declined significantly in recent years (Calmore, 1986; Van Valey, Roof, \& Wilcox, 1977), and that different values and customs of ethnic and racial groups are still undervalued by the society. Several studies suggest that racial inequality has not improved but has changed in nature (Crosby \& Clayton, 1990; Thomas, 1990), from obvious forms to subtle forms of racial isolation and inequality (Thomas, 1990). Overt racism has been transformed into symbolic racism making people more likely to express hostility against people of color indirectly by opposing social policies such as busing or electing candidates of color (Kinder \& Sears, 1981; Sears, 1988). 
When individuals are exposed to an atmosphere of unequal treatment because of their race, substantial discomfort may result from the experience of being undervalued. This discomfort is an emotional response to perceived discrimination that is translated into physical symptoms, in particular, physically manifested in stress-related health problems such as hypertension or depression. For example, recent research by Armstead et al. (1989) showed that an increase in blood pressure was significantly higher when racist stimuli were given than when race-neutral, anger-provoking stimuli were given to African-American college students. In addition, a number of studies showed that race is a significant factor in predicting psychosomatic problems such as depression and phobia (Aldwin \& Greenberger, 1987; Brown, Eaton, \& Sussman, 1990; Golding \& Burnam, 1990). However, these studies did not find a direct relationship between these psychosomatic problems and racism. The perception of race discrimination varies among individuals, who respond differently depending on how they appraise the situation. What causes the difference between individuals who affectively respond to racism and those who do not? Some individuals might possess 
characteristics that help them deal with negative experiences of racism. How people of color appraise and process racism has not been widely studied.

Traditionally, a psychologically healthy individual was believed to possess realistic perceptions of self, the world, and the future. However, a number of studies have found, instead, that many healthy people hold positive illusions (Alloy \& Abramson, 1979; Greenwald, 1980; Taylor, 1983), which are defined by Taylor and Brown (1988) as "unrealistically positive views of self, exaggerated perceptions of personal control, and unrealistic optimism" (P.193). Realistic perceptions of self, future, and personal control appear to be more characteristic of depressed individuals than of nondepressed individuals (Taylor \& Brown, 1988). Taylor's (1989) study of victims of breast cancer indicate that exaggerated perceptions of personal control, one of the components of positive illusions, can help individuals cope with the negative life experience. In other words, the patients dealt with the threat of the cancer by believing that their personalities can control the cancer. Another study by Taylor (1993) showed that HIV-seropositive (HIV+) subjects had higher optimism 
about surviving AIDS than did HIV-seronegative (HIV-) subjects. Higher optimism helped reduce distress among the HIV-positive subjects and did not decrease constructive behavior.

If these illusions help individuals live positively with major life tramas, might they also positively affect people of color who deal with racism every day. In order to maintain a healthy life, healthy individuals may possess positive illusions such as high self-esteem, controllability, and an optimistic view of the outside world. If so, those individuals who possess these positive illusions might appraise racism positively, in other words, perceive less racism than those without positive illusions. This study attempts to investigate the role of personal control, optimism, and self-enhancement, the constructs inherent in illusions, as they relate to perceptions of racism. Race and Racism

Race. A race is a category of people with common biological traits passed from generation to generation (Macionis, 1989). Biologists identify three major racial classifications: Caucasoids, Negroids, and Mongoloids. In the United States, however, many of these classifications are blurred. For example, 
research shows that white and African Americans are quite mixed. Thus, many African Americans have various proportions of Caucasoid genes, and the opposite may be true of people who appear to be White. Mongoloid genes of native Americans have also spread through the American population (Macionis, 1989; Schaefer, 1988). As a result of frequent migration and exploration, there are no mutually exclusive races. Therefore, the racial classification that is often used in the media or in everyday conversation is based on arbitrary social classifications.

In this paper, the term "people or students of color" refers to the individuals who categorize themselves as non-Caucasoids. Black or AfricanAmerican is used for seemingly Negroid individuals; White or Euro-American is used for seemingly Caucasoid individuals; Hispanic or Latino-American is used for the individuals whose ancestors originally inhabited Mexico or South America and who biologically mixed with Caucasoids, Mongoloids, and sometimes Negroids; and Asian-American is used for seemingly Mongoloid individuals whose ancestries are from Asia.

Racism. Macionis (1989) defines racism as "the belief that one racial category is innately superior or 
inferior to another" (p.285). According to van den Berghe (1967), racism is "the virulent brand of the disease, that is, the intense, overt, violent hatred of racial outgroups" (p.11). Racism results from race prejudice through the exercise of power against a racial group defined as inferior by individuals and institutions, with the intentional or unintentional support of the entire culture (Jones, 1972).

Ezorsky (1991) argues that there are two types of racism, overt and institutional. Overt racism occurs when an individual's benefit is withheld because of the perpetrator's racial bias against the victim. Thus a professor who treats a student of color in a negative manner because of the student's race is practicing overt racism. Institutional racism, however, occurs when the educational, political, and social institutions use race-neutral practices that favor one group over another as the result. For example, universities often set an exam score criterion to select candidates for graduate programs. If students of color tend to perform poorly on exams which are standardized on samples drawn mainly from the white population, such students may be excluded disproportionately from the selection regardless of 
their other capabilities. Yet this practice is treated by the institution as race-neutral. Positive Illusions and Personal Health Maslow (1970) developed his idea of selfactualization as a process in developing a healthy personality. Healthy individuals, according to Maslow, reject unrealistic fantasies and prefer to perceive unpleasant realities. Jourard and Landsman (1980) have also stated that a healthy personality depends on an accurate perception of and knowledge about the world. This traditional view assumes that healthy individuals gather accurate data from their environments and use it to make adequate decisions. However, this view does not seem to apply in real life situations. A study by Kahneman and Tversky (1972) shows that people collect incomplete and biased data by using shortcuts or heuristics. Many researchers have documented that normal individuals possess unrealistically positive views of themselves (Alloy, \& Abramson, 1979; Greenwald, 1980). Evidence of illusions has also been found in experimental work. For example, Martin and his colleagues (1984) report that nondepressed male students perceive their own control over successful outcomes to be greater than depressed male students, 
despite the fact that their performance is identical.

In Taylor's (1989) work with positive illusions, she has challenged the traditional view that accurate perceptions of reality are the cornerstone of mental health. She defines an illusion as

A perception that represents what is perceived in a way different from the way it is in reality. An illusion is a false mental image or conception which may be a misinterpretation of a real appearance or may be something imagined. It may be pleasing, harmless or even useful (p.44).

Drawing from laboratory studies in cognitive psychology, field interviews with people experiencing stressful events, and surveys of the general public, Taylor shows that mental and physical well-being can be enhanced by unrealistic optimism about one's self, the world, and the future. Her research with disaster victims, cancer patients and ordinary people facing crises illustrates how many of these individuals achieve greater levels of life satisfaction after they experience tragic events. She has acknowledged that people with healthy minds do not necessarily have realistic perceptions of self, the world, and the future. Taylor and Brown (1988) have identified three illusions: 1) unrealistically positive views of the self, 2) exaggerated perceptions of personal control, 
and 3) unrealistic optimism.

Unrealistically Positive Views of Self. Research on self-serving biases in the attribution process shows that most people are more likely to attribute positive rather than negative outcomes to the self (Bradley, 1978; Miller \& Ross, 1975). Although traditional psychologists believe that healthy individuals possess both positive and negative perceptions of self based on reality, a significant body of literature indicates that most individuals possess unrealistically positive views of self (Alloy, \& Abramson, 1979; Greenwald, 1980). Many people believe that they possess more positive traits than negative traits (Alicke, 1985; Brown, 1986).

Exaggerated perceptions of personal control. Research has found that people often perceive personal control in situations that are actually determined by chance. For example, people tend to think that they have more control when they throw dice than when someone else throws for them (Langer, 1975). Realistic perceptions of personal control are found more in depressed people than in nondepressed people (Alloy, \& Abramson 1979).

Unrealistic optimism. Most people are inclined to 
Perceived Racism

be future oriented (Taylor \& Brown, 1988). Research shows that most people believe the future will be better than the present, and the present is better than the past (Brickman, Coates, \& Janoff-Bulman, 1978). Taylor and Brown (1988) present their theory with the following caveats. First, there is a paucity of research examining the direct links between illusions and positive affect, illusions and social skills, and illusions and intellectual functioning. Further research is suggested especially to examine the effect of illusions on positive affect, which in turn, reflects the influence of illusions on mental health. second, there is a limitation in connecting positive illusions with common criteria of mental health. For instance, psychologically healthy people need to grow in order to change positively, and the change is often motivated by negative experiences. Consequently, unrealistic optimism may seem to disturb the process of psychological growth in healthy people. Third, there might be long-term limitations to positive illusions. Unrealistic optimism may lead people to ignore risks. For example, diabetic patients with unrealistic optimism might not attempt to control their blood glucose, or might ignore guidance from physicians, 
leading them into serious complications.

The goal of this study was to apply the constructs of Taylor's theory of positive illusions to perceived racism. For this study, experiences of racism among people of color would be considered as discomfort which was caused by the negative feedback of the dominant population. This negative feedback was manifested as discrimination in housing, politics, and stereotypes. Its purpose was to examine the effects of personal control, optimism, and self-esteem on perceived racism among people of color represented by Black/AfricanAmericans, Asian-Americans, and White-Americans. The White population, generally considered to be the dominant race in this society, was used as a control group.

Hypotheses

According to previous studies, positive illusions would help people live positively with negative life experiences. It was hypothesiized that the constructs of illusions (self-esteem, controllability, and optimism) would change in how people perceive racism. The following hypotheses were tested.

Hypothesis 1. People of color and whites perceive racism differently. Whites, as the dominant race in 
the society, would be less likely to encounter

stereotypes, predudice, or unfair treatment because of their race, although discrimination occurs for other reasons, such as gender and sexual orientaion. Therefore, it was hypothesized that members of the White group perceives racism differently from members of color.

Hypothesis 2. People of color with high selfesteem would perceive less racism than people of color with low self-esteem. The level of self-esteem among Whites would not influence perceived racism.

Hypothesis 3. People of color with high controllability would perceive less racism than people of color with less controllability. The level of controllability among whites would not influence perceived racism.

Hypothesis 4. People of color with high optimism would perceive less racism than people of color with low optimism. The level of optimism among whites would not influence perceived racism.

Method

\section{Subjects}

Thirty-seven African-American, 64 Asian-American, and 100 White-American students (101 females, 100 males 
and mean age of 25 years) were recruited at portland State University. The subjects were recruited through contacting friends, minority associations, and support groups. All students selected for the study were fluent in English, so that all of the participants were capable of understanding racist comments and attitudes in everyday environments. Table 1 presents the demographic information. The mean age of AsianAmerican students was much younger than those of African- and White-American students. Also, there were more females than males in the Asian-American group, while males made up the majority of the other racial groups.

Insert Table 1 about here

\section{Procedure}

The questionnaires were distributed to students individually or in groups whenever it is convenient for them. The researcher explained that the purpose of the study was to examine race relations on campus. The researcher also told students that there would be no penalty involved if they decided not to participate. 
Perceived Racism

Measures

Perceived racism (see Appendix B, part I).

Twenty-two questions selected from a scale developed by Dansby and Landis (1991) were used. Those questions assumed to contain two dimensions, Deferential Authority Behaviors dimension and Equal Opportunity Behaviors dimension. The questionnaire was recently revised from a military version to a student version by the original researchers. The researchers obtained Cronbach's Alpha of .89 from the military version.

These questions assessed the subjects' perceptions and interpretations of university events and attitudes. Therefore, the questionnaire indicated that students need not have personally seen or experienced the events asked about on the questionnaire.

Self-esteem (see Appendix B, part II). Rosenberg's (1965) Self-Esteem scale was administered. The scale consisted of 10 items, and responses were made on 4-point Likert scales with endpoints "Strongly agree" and "Strongly disagree". This scale has been a well-established measure of self-esteem and is often used in social psychological studies. A test-retest correlation over 2 weeks was .85 , and Guttman scale reproducibility coefficient of .92 was obtained (Silber 
Perceived Racism

\& Tippett, 1965) .

Controllability (see Appendix B, part III).

Twenty-five of 29 items from the Internal-External Locus of Control Scale (Rotter, 1966) were used. Four items were inadvertently omitted from the questionnaire. Reliability coefficient of .73 was obtained for the 25 items. Internal statements were paired with external statements, and one point was given for each external statement selected. This scale was frequently used with college students. Rotter obtained an internal consistency coefficient of . 70 . Optimism (see Appendix B, part IV). The Life orientation Test (LOT) which consisted of 12 items developed by Scheier and Carver (1985) were used. This scale was developed as a measure of optimism by assessing generalized outcome expectancies. Responses were "true" or "false". The researchers obtained Cronbach's Alpha of .76 for internal consistency and Test-Retest reliability of .79 .

Demographic information (see Appendix B, part V). Demographic information were solicited, including assessments of gender, ethnicity, and age.

Results

Factor Analysis of Perceived Racism Measure 
Exploratory factor analysis was performed to determine construct and discriminant validity for the perceived racism scale. The sample size was 201. Eigenvalues from a principal components analysis were $6.05,4.50,1.11,0.99,0.93,0.87,0.83,0.70,0.67$, $0.62,0.58,0.54,0.49,0.47,0.45,0.41,0.38,0.378$, $0.35,0.25,0.245$, and 0.19. There was a sharp drop in eigenvalues between the second and third factors. A two-factor solution and a three-factor solution were found using the common factor model followed by an oblimin rotation. The two-factor model accounted for $47.9 \%$ of the total variance and three-factor solution accounted for $53 \%$

Patterns of high and low loadings across items were examined to define factor labels. The two-factor solution was more interpretable than the three-factor solution and illustrated simple structure. Table 2 presents the factor loadings for the two-factor model.

Insert Table 2 about here

In the two-factor solution, twelve items (item numbers $1,3,5,7,9,11,13,15,16,17,19$, and 21) loaded 
high on Factor 1 and low on Factor 2. Factor 1 can be described as Equal Opportunity (EO) racism. High responses to the twelve items loading on Factor 1 reflect the racist atmosphere among students on campus. Items in Factor 1 uniquely accounted for $12.4 \%$ of the total variance.

Ten items (item numbers $2,4,6,8,10,12,14,18,20$, and 22) loaded high on Factor 2. Factor 2 can be described as Perceived Authority (AUT) racism. High responses to items loading on Factor 2 reflect racism from faculty members on campus. Items in Factor 2 uniquely accounted for $10.4 \%$ of the total variance. The interfactor correlation of the two factors was .097 .

Cronbach's alpha was calculated to examine the internal consistency reliabilities of the two dimensions of the perceived racism scale. Reliability of .89 for Factor 1, the EO racism dimension, and .87 for Factor 2, the AUT racism dimension, were obtained. Multiple Regressions to Test Hypotheses

Three hierarchical multiple linear regression (MLR) analyses were performed for each dimension of perceived racism (EO and AUT), one for each positive illusion variable (self-esteem, controllability, and 
optimism). Each MLR evaluated the contribution of racial groups, the illusion variable, and the interaction of race and illusion on perceived racism. These analyses identified which variables contributed a significant amount of variance to the perception of racism.

Two dummy coded variables were created for the three racial groups; African-American, Asian-American, and White-American. White-American was coded as a control group. In the first step, the two dummy coded race variables were entered in the model to test the effect of race on perceived racism. As expected, a significant effect of race on EO racism was found, $\underline{F}(2$, $185)=56.43, \underline{\mathrm{p}}<.001$, accounting for $38 \%$ of variance. T-tests associated with the regression coefficients were examined and both the African- and Asian-American groups were significantly different from the whiteAmerican group $(\underline{t}=9.77, \underline{p}<.001$, and $\underline{t}=7.017, \underline{p}<$ .001 respectively). Thus, the findings reveal that both African- and Asian-American groups perceived EO racism significantly higher than the white-American group did.

The effect of race on AUT racism was also significant, $\underline{F}(2,176)=8.09, \underline{p}<.001$, accounting for 
only $8 \%$ of variance. T-tests were examined and revealed that the African-American group perceived AUT Racism significantly higher than the White-American group, $\underline{t}=4.02, \underline{p}<.001$. Perception of AUT racism among the Asian-American group was not significantly different from the White-American group. The means and standard deviations for perceived EO racism and AUT racism for each group are shown in Table 3 .

Insert Table 3 about here

In the second step, self-esteem was entered. The effect of self-esteem on EO Racism was not significant. However, the perception of both Asian- and AfricanAmerican groups were still significantly different than the White-American group. The effect of self-esteem on AUT Racism was significant, $\underline{t}=-2.034, \underline{p}<.05$, accounting for $2.1 \%$ of the variance in AUT racism. Only the African-American group remained significantly different than the White-American group, $\underline{t}=4.33, \underline{p}<$ .001 .

In the third step, interaction variables of selfesteem and race were entered in the model. The 
increment in $R$ square from step two to step three tested the effect of the interaction, removing race and self-esteem differences. The increment in $\mathrm{R}$ square due to the interaction for EO racism was not significant and neither was the interaction for AUT racism. Tables 4 and 5 present incremental F-values.

Insert Table 4 and 5 about here

The same hierarchical MLR procedures were performed for controllability. The effect of controllability on EO Racism was not significant. However, the perception of both African-and AsianAmerican groups were still significantly different from the White-American group $(\underline{t}=9.50, \underline{p}<.001$, and $\underline{t}=$ $6.09, \underline{p}<.001$ respectively). The effect of controllability on AUT racism was significant, $\underline{t}=-$ $4.364, \mathrm{p}<.001$, accounting for $10 \%$ of the variance. Only the African-American group remained significantly different from the White-American group $(\underline{t}=3.81, \underline{p}<$ $.001)$

The interaction variables of controllability and race were entered in the model. The increment in $R$ 
square from step two to three tested the effect of the interaction, removing race and controllability differences. The increments in $\mathrm{R}$ square due to the interaction for $\mathrm{EO}$ and AUT racism were both not significant. Tables 6 and 7 present the incremental Fvalues.

Insert Table 6 and 7 about here

Again the same hierarchical MLR procedures were performed for optimism. The effect of optimism on EO racism was not significant. The level of perception of both African- an Asian-American groups remained significantly higher than the White-American group $(\underline{t}=$ $9.29, \underline{p}<.001$, and $\underline{t}=6.59, \underline{p}<.001$ respectively). The effect of optimism on Perceived AUT racism was significant, $\underline{t}=-2.019, \underline{p}<.05$, accounting for $2 \%$ of the variance. T-tests were examined and the AfricanAmerican group remained significantly different than the White-American group, $t=3.79, \mathrm{p}<.001$.

The interaction variables of optimism and race were entered in the model. The increment in $R$ square from step two to step three for both Perceived EO 
racism and Perceived AUT racism were not significant. Tables 8 and 9 present incremental F-values.

\section{Discussion}

The present study examined the effects of personal control, optimism, and self-esteem on perceived racism among people of color represented by African-, Asian-, and White-American students at Portland state University.

The racism scale in this study was found to contain two dimensions, Equal Opportunity (EO) racism and Authority (AUT) racism. Twelve questions were included in the EO racism scale. The EO racism scale reflected the racist atmosphere among peer students on campus, such as "Campus special events were attended by both majority and minority students". Ten questions were included in the AUT racism scale. The AUT racism scale reflected racism from faculty members, such as "A professor giving a lecture took more time when answering questions from whites than when answering questions from minorities". 
The findings revealed results which both support and contradict the predictions. Both African- and Asian-American students perceived a racist atmosphere from peer students (EO racism) to a significantly higher degree than the White-American students did. However, only African-American students perceived greater racism from faculty members (AUT racism) than the White-American students. The Asian-American students' perception did not differ from the WhiteAmerican students' perception of racism from faculty members. The findings revealed that the female students perceived higher AUT racism $(\underline{r}=.145, \underline{p}=$ $.05)$, and higher EO racism $(\underline{r}=.110, \underline{p}=.13)$ than the male students. Also, higher perception of AUT racism was correlated with higher age $(\underline{\underline{x}}=.264, \underline{\mathrm{p}}<.001)$, and higher perception of EO racism was correlated with younger age $(\underline{r}=.07, \underline{p}=.34)$.

None of the illusions had an effect on perceived EO racism. However, in contrast to the effect on perceived EO racism, all types of illusions (selfesteem, controllability and optimism) had a significant effect on perceived racism from faculty members (AUT racism). Higher perception of AUT racism was correlated with less self-esteem $(\underline{r}=-.089, \underline{p}=.120)$, 
less controllability $(\underline{\mathrm{r}}=-.319, \underline{\mathrm{p}}<.001)$, and less optimism $(\underline{\mathbf{r}}=-.144, \underline{\mathrm{p}}=.03)$. However, there were no significant interactions between illusions and race for AUT racism. This limits any discussion of observed correlations of appraisal of AUT racism with other variables. It is possible that the sample size in this study was too small to show significant interactions. Further research with larger samples might reveal important details of the relation of perceived racism with the other variables in this study.

The findings suggest that the illusions, especially controllability, might change individuals in how they perceive racism when the racism is practiced by authorities. According to Taylor's (1989) study of victims of breast cancer, individuals with high controllability believed that their personalities can control the cancer. Another study by Taylor et al. (1993) showed that higher optimism helped reduce distress among the HIV-positive individuals. It may be that illusions are effective only in situations that are serious enough to influence an individual's life. The reason that illusions did not affect perceived EO racism could be explained by the degree of seriousness. In other words, racist attitude of professors and 
faculty members have a much more serious effect on students' everyday lives than the student atmosphere on campus. More research is needed to clarify the issue of perceived racism and positive illusions.

This study found differences in perceived racism between three racial groups. The African-Americans especially showed a greater difference in perception of authority racism than the Asian-Americans when compared to the White-Americans. The reason for the similar perception of authority racism, not EO racism, among the Asian- and the White-Americans is not clear. However, Asian-Americans immigrated to the United States from diverse countries for various reasons. In contrast, African-Americans have an unique history of oppression at this country's beginning. Therefore, the historical background of White-Americans may be more similar to that of Asian-Americans than that of African-Americans. Consequently, it is likely that the perception of racism among White-Americans is similar to that of Asian-Americans than African-Americans.

It is also important to recognize that many AsianAmericans in this study were recent immigrants from Southeast Asia. The perception of racism by recent Asian-American immigrants from Southeast Asia may be 
different from that of Asian-Americans whose ancestors came to the United States several generations ago, and who came mainly from Northern Asia. Future research needs to seek subjects of more diverse ethnic groups to see how people of color perceive racism differently according to their historical background.

College students of color are probably more assimilated into white culture than persons of color in the general population. White students are also more exposed to multi-cultural environments than the general population. Therefore, it is reasonable to think that the level of perceived racism among college students may be less than that of the general population.

Research on racial discrimination suggests that we should consider the nature of tolerance and personality structure, and economical and political structure at the time of measurement (van den Verghe, 1967). For example, the degree or form of discrimination toward people of color in the 70's differs from that in the 90's because of civil rights movements, large increases in the number of Asian immigrants, and economic changes. Consequently, perceived discrimination can change over time. 
References

Aldwin, C., Greenberger, E. (1987). Cultural

differences in the predictors of depression.

American Journal of Community Psychology, 15, 6 , 789-811.

Alicke, M. D. (1985). Global self-evaluation as

determined by the desirability and controllability

of trait adjectives. Journal of Personality and

Social Psychology, 49, 1621-1630.

Alloy, L. B., \& Abramson, L. Y. (1979). Judgment of contingency in depressed and non depressed students: Sadder but wiser? Journal of Experimental

Psychology: General, 108, 441-485.

Armstead, C. A., Lawler, K. A., Gorden, G., Cross, J.,

\& Gibbons J. (1989). Relationship of racial

stressors to blood pressure responses and anger

expression in black college students. Social

Psychology, 8(5), 541-556.

Bennett, I., Jr. (1964). Before the Mayflower: A

History of the Negro in America. Baltimore: Penguin Books . 
Bradley, G. W. (1978). Self-serving biases in the attribution process: A reexamination of the fact or fiction question. Journal of Personality and Social Psychology, 36, 56-71.

Brickman, P., Coates, D., \& Janoff-Bulman, R. (1978). Lottery winners and accident victims: Is happiness relative? Journal of Personality and Social Psychology, 35, 917-927.

Brown, D. R. \& Eaton, W. W., Sussman, L. (1990).

Racial differences in prevalence of phobic disorders. The Journal of Nervous and Mental Disease, 178, $\underline{7}, 434-440$.

Brown, J. D. (1986). Evaluations of self and others: Self-enhancement biases in social judgments. Social Cognition, 4 , 353-376.

Calmore, J. O. (1986). National housing policies and black America: Trends, issues, and implications. The State of Black America 1986. New York: National Urban League. Crosby, F. \& Clayton S. (1990). Affirmative action and the issue of expectancies. Journal of Social Issues, 46, 61-79. 
Dansby, M. R. \& Landis D. (1991). Measuring equal opportunity climate in the military environment. International Journal of Intercultural Relations, $15,389-405$.

Ezorsky, G. (1991). Racism and Justice. New York: Cornell.

Golding, J., Burnam, A. (1990). Immigration, stress, and depressive symptoms in a Mexican-American community. The Journal of Nervous and Mental Disease, 178, 3, 161-170.

Greenwald, A. G. (1980). The totalitarian ego: Fabrication and revision of personal history. American Psychologist, 35, 603-618. Jones, J. M. (1972). Prejudice and Racism. MA: Addison-Wesley. Jourard, S. M., Landsman T. (1980). Healthy Personality, Fourth Ed. New York: Macmillan. Kahneman, D., \& Tversky, A. (1972). Subjective probability: A judgment of representativeness. Cognitive Psychology, $3,430-454$. Kinder, D. R. \& Sears, D. O. (1981). Prejudice and politics: Symbolic racism versus racial threats to the good life. Journal of Personality and Social Psychology, 40, 414-431. 
Langer, E. J. (1975). The illusion of control. Journal of Personality and Social Psychology, 32, $311-328$.

Martin, D. J., Abramson, L. Y., \& Alloy, L. B. (1984). Illusion of control for self and others in depressed and nondepressed college students. Journal of Personality and Social Psychology, 46, 126-136. Maslow, A. H. (1970). Motivation and Personality, Second ed. New York: Harper \& Row. Macionis, J. J. (1989). Sociology, Second ed. New Jersey: Prentice-Hall. Miller, D. T., \& Ross, M. (1975). Self-serving biases in attribution of causality: Fact or fiction? Psychological Bulletin, 82, 213-225. Rosenberg, M. (1965). Society and the Adolescent SelfImage. Princeton, New Jersey: Princeton University Press. Rotter (1966). Generalized expectancies for internal versus external control of reinforcement. Psychological Monographs, 80 ( 1 Whole No. 609). Schaefer, R. T. (1988). Racial and Ethnic Groups, Third ed. Glenview: Scott. 
Scheier, M. F., \& Carver, C. S. (1985). Optimism, coping, and health: Assessment and implications of generalized outcome expectancies. Health Psychology, 4(3), 219-247.

Sears, D. O. (1988). Symbolic racism. In P. Katz \& D. Taylor (Eds.), Eliminating racism: Profiles in controversy (pp.53-84). New York: Plenum.

Silber, E. and Tippett, J. (1965). Self-esteem: clinical assessment and measurement validation. Psychological Reports, 16, 1017-1071.

Taylor, S. E. (1983). Adjustment to threatening events: A theory of cognitive adaptation. American Psychologist, 38, 1161-1173.

Taylor, S. E. (1989). Positive Illusions. New York: Basic Books, 177 .

Taylor, S. E. \& Brown, J. D. (1988). Illusion and well-being: A social psychological perspective on mental health. Psychological Bulletin, 103, 193210

Thomas, D. A. (1990). The impact of race on managers' experiences of developmental relationships (mentoring and sponsorship): An intra-organizational study. Journal of Organizational Behavior, 11, 479492 . 
Perceived Racism

32

van den Berghe, P. L. (1967). Race and Racism. New York: Wiley.

Van Valey, T. L., Roof, W. C., \& Wilcox J. E. (1977) . Trends in residential segregation. 
Perceived Racism

Table 1

Demographic information

Male Female $\underline{n}$ Full-time Part-time Mean Student Student Age

African-

American

$19 \quad 18$

37

30

7

28.8

Asian-

American

23

41

64

59

5

22.5

White-

American

58

42

100

86

14

26.2

Tota 1

100

101

201

175

26

25.4 
Table 2

\section{Factor Loadings}

Item No. Factor 1 Factor 2

\begin{tabular}{|c|c|c|}
\hline 1 & .62870 & -.02571 \\
\hline 2 & -.04486 & .62204 \\
\hline 3 & .71351 & -.03478 \\
\hline 4 & .05524 & .67878 \\
\hline 5 & .65878 & -.03226 \\
\hline 6 & .11851 & .61687 \\
\hline 7 & .78955 & -.01247 \\
\hline 8 & .03219 & .78641 \\
\hline 9 & .58829 & .11983 \\
\hline 10 & .10109 & .70860 \\
\hline 11 & .56879 & .32309 \\
\hline 12 & .11380 & .64245 \\
\hline 13 & .60697 & .03411 \\
\hline 14 & -.16524 & .52102 \\
\hline 15 & .72303 & -.01115 \\
\hline 16 & .50580 & -.03310 \\
\hline 17 & .71455 & -.00113 \\
\hline 18 & .01991 & .81414 \\
\hline 19 & .64371 & -.06678 \\
\hline 20 & .02813 & .47202 \\
\hline 21 & .53730 & -.02505 \\
\hline 22 & -.19448 & .52041 \\
\hline
\end{tabular}


Perceived Racism

Table 3

Mean Scores and Standard Deviation for EO and AUT racism for each Racial Group

EO Racism

AUT Racism

\begin{tabular}{lllll}
\hline & Mean & SD & Mean & SD \\
& & & & \\
\hline $\begin{array}{l}\text { African- } \\
\text { Americans }\end{array}$ & 32.18 & 7.66 & 31.31 & 7.97 \\
$\begin{array}{l}\text { Asian- } \\
\text { Americans }\end{array}$ & 33.59 & 6.82 & 26.40 & 5.75 \\
$\begin{array}{l}\text { White- } \\
\text { Americans }\end{array}$ & 22.19 & 6.99 & & \\
& & & 25.05 & 8.37 \\
\hline
\end{tabular}


Perceived Racism

Table 4

Hierarchical MLR: The Effect of Self-esteem on Perceived EO Racism

\begin{tabular}{lcccc}
\hline & $\begin{array}{c}\mathrm{R}^{2} \\
\text { Increment }\end{array}$ & $\mathrm{df}$ & $\mathrm{F}$ & $\begin{array}{c}\text { significance } \\
(\mathrm{p}=.001)\end{array}$ \\
\hline $\begin{array}{l}\text { Race } \mathrm{R}_{1}^{2} \\
\begin{array}{l}\text { Self-esteem } \\
\mathrm{R}_{2}^{2}-\mathrm{R}_{1}^{2}\end{array}\end{array}$ & 0.38 & 2,185 & 56.43 & sig. \\
$\begin{array}{l}\text { Interaction } \\
\mathrm{R}_{3}^{2}-\mathrm{R}_{2}^{2}\end{array}$ & 0 & 1,184 & 2.18 & not sig. \\
\hline
\end{tabular}

Table 5

Hierarchical MLR: The Effect of Self-esteem on

Perceived Authority Racism

\begin{tabular}{lcccc}
\hline & $\begin{array}{c}\mathrm{R}^{2} \\
\text { Increment }\end{array}$ & df & $\mathrm{F}$ & $\begin{array}{c}\text { significance } \\
(\mathrm{p}=.001)\end{array}$ \\
\hline Race $\mathrm{R}_{1}^{2}$ & 0.08 & 2,176 & 8.09 & sig. \\
$\begin{array}{l}\text { Self-esteem } \\
\mathrm{R}_{2}^{2}-\mathrm{R}_{1}^{2}\end{array}$ & 0.03 & 1,174 & 4.14 & sig. \\
$\begin{array}{l}\text { Interaction } \\
\mathrm{R}_{3}^{2}-\mathrm{R}_{2}^{2}\end{array}$ & 0.02 & 2,172 & 2.84 & not sig. \\
\hline
\end{tabular}


Table 6

Hierarchical MLR: The Effect of Controllability on

Perceived EO Racism

\begin{tabular}{lcccc}
\hline & $\begin{array}{c}\mathrm{R}^{2} \\
\text { Increment }\end{array}$ & df & $\mathrm{F}$ & $\begin{array}{l}\text { Significance } \\
(\mathrm{p}=.001)\end{array}$ \\
\hline $\begin{array}{l}\text { Race } \mathrm{R}_{1}^{2} \\
\text { Controllability } \\
\mathrm{R}_{2}^{2}-\mathrm{R}_{1}^{2}\end{array}$ & 0.38 & 2,185 & 56.43 & sig. \\
$\begin{array}{l}\text { Interaction } \\
\mathrm{R}_{3}^{2}-\mathrm{R}_{2}^{2}\end{array}$ & 0.02 & 1,152 & 2.04 & not sig. \\
\hline
\end{tabular}

Table 7

Hierarchical MLR: The Effect of Controllability on

Perceived Authority Racism

\begin{tabular}{|c|c|c|c|c|}
\hline & $\begin{array}{c}\mathrm{R}^{2} \\
\text { Increment }\end{array}$ & $\mathrm{df}$ & $\mathbf{F}$ & $\begin{array}{l}\text { Significance } \\
(\mathrm{p}=.001)\end{array}$ \\
\hline Race $R_{1}^{2}$ & 0.08 & 2,176 & 8.09 & sig. \\
\hline $\begin{array}{l}\text { Controllabil } \\
\mathrm{R}_{2}^{2}-\mathrm{R}_{1}^{2}\end{array}$ & ${ }^{\text {ity }} 0.10$ & 1,145 & 19.04 & sig. \\
\hline $\begin{array}{l}\text { Interaction } \\
R_{3}^{2}-R_{2}^{2}\end{array}$ & 0.04 & 2,143 & 2.88 & not sig. \\
\hline
\end{tabular}


Perceived Racism

Table 8

Hierarchical MLR: The Effect of optimism on Perceived EO Racism

\begin{tabular}{llllc}
\hline & $\begin{array}{c}\mathrm{R}^{2} \\
\text { Increment }\end{array}$ & $\mathrm{df}$ & $\mathrm{F}$ & $\begin{array}{c}\text { Significance } \\
(\mathrm{p}=.001)\end{array}$ \\
\hline $\begin{array}{l}\text { Race } \mathrm{R}_{1}^{2} \\
\begin{array}{l}\text { Optimism } \\
\mathrm{R}_{2}^{2}-\mathrm{R}_{1}^{2}\end{array}\end{array}$ & 0.38 & 2,185 & 56.43 & sig. \\
$\begin{array}{l}\text { Interaction } \\
\mathrm{R}_{3}^{2}-\mathrm{R}_{2}^{2}\end{array}$ & 0.02 & 1,176 & 2.83 & not sig. \\
\hline
\end{tabular}

Table 9

Hierarchical MLR: The Effect of optimism on Perceived Authority Racism

\begin{tabular}{lcccc}
\hline & $\begin{array}{c}\mathrm{R}^{2} \\
\text { Increment }\end{array}$ & $\mathrm{df}$ & $\mathrm{F}$ & $\begin{array}{c}\text { Signigicance } \\
(\mathrm{p}=.001)\end{array}$ \\
\hline $\begin{array}{l}\text { Race } \mathrm{R}_{1}^{2} \\
\begin{array}{l}\text { Optimism } \\
\mathrm{R}_{2}^{2}-\mathrm{R}_{1}^{2}\end{array}\end{array}$ & 0.08 & 2,176 & 8.09 & sig. \\
$\begin{array}{l}\text { Interaction } \\
\mathrm{R}_{3}^{2}-\mathrm{R}_{2}^{2}\end{array}$ & 0.02 & 1,167 & 4.08 & sig. \\
\hline
\end{tabular}


Perceived Racism

Appendix A

INFORMED CONSENT FORM

I , agree to participate in

the research project about race relations on campus conducted by Miyako Hayashi who has told me that the purpose of the study is to examine race relations on campus.

She has offered to answer any questions about the study and what I am expected to do.

I understand that the study involves a questionnaire that lasts approximately 20 to 30 minutes, and that in addition to personal inconvenience, the questionnaire involves sensitive issues which may make me feel uncomfortable.

Though I may not receive any direct benefit from taking part in this study, the results may contribute to better understanding of race relations on campus in the future.

All information I provide will be confidential and the names of all people in the study will remain anonymous.

I understand that I may withdraw from this study without affecting my course grade or my relationship with Portland State University.

Signature:

Date:

If you have problems that are the result of your participation in this project, please contact the chair of the Human subjects Research Committee, the office of Grants and Contracts, 105 Neuberger Hall, Portland state University, (503) 725-3417. 
Perceived Racism

40

Appendix B

SOCIAL CLIMATE SURVEY

\section{INTRODUCTION}

This survey is intended to help identify equal opportunity climate and examine self-esteem, controllability and optimism. We are trying to gauge the potential frequency of certain kinds of actions. We have gathered a list of actions that might happen at the university. In PART I of the survey, we ask that you estimate the chances that the action occurred during the past term.

Information provided by respondents will be treated confidentially.

\section{INSTRUCTIONS}

Please fill in the responses that most accurately reflect your perceptions. There are no right or wrong answers. Your responses will remain confidential so please answer frankly. If you have trouble understanding a question, answer to the best of your knowledge, even if your have not personally experienced it.

This survey is made up of several parts. Please read the instructions carefully at the beginning of each part.

For the purposes of this survey, "minority" includes male or females of the following racial/ethnic groups:

Black or African-American

Hispanic or Latino-American

Asian-American or Pacific Islanders

Native American/Alaskan native

"Majority" or "White" includes males and females not in the groups listed above.

REMEMBER: You need not have personally seen or experienced these events. We only want your opinion on the likelihood that these events occurred at Portland state University during the past term. 
PART I

Use the following scale to make your judgments:

$1=$ There is a very high chance that the action occurred.

$2=$ There is a reasonably high chance that the action occurred.

3 = There is a moderate chance that the action occurred.

4 = There is a small chance that the action occurred.

5 = There is a almost no chance that the action occurred.

During the past term at the university:

1.Campus special events (athletic programs, etc) were attended by both majority and minority students. ( )

2. A faculty member made demeaning comments about races other that his/her own. ( )

3. White students were seen socializing out of class in public with other ethnic minorities on campus. ( )

4.A minority student was assigned less desirable living quarters than a White. ( )

5. White faculty, staff and administrators were seen socializing with members of other races off-campus. ( )

6. A student government official changed a committee assignment after he noticed that two ethnic minorities had been assigned to same committee. ( )

7. White students were seen socializing with members of other races off-campus (eg., at restaurants, bars, and concerts $)$. ( )

8. A professor giving a lecture took more time when answering questions from whites than when answering questions from minorities. ( )

9.A new minority student joined a campus organization and quickly developed close white friends from within the unit. $($ )

10.A qualified minority faculty member was denied sabbatical leave by his/her dean. A white faculty with the same qualifications was given the opportunity. ( )

11. When a professor held meetings, minorities, as well as whites were asked to contribute suggestions to solve problems. ( ) 
12. A university official gave a minority student a more severe punishment for cheating on a class assignment. A white who committed the same offense was given a less severe penalty. ( )

13. Members of each race were seen socializing together on campus. ( )

14. A black person walking across campus after midnight was stopped by campus police. ( )

15. White students joined minority friends for lunch at the same table in the university cafeteria. ( )

16. Members of various ethnic/racial backgrounds (including whites) gathered regularly and discussed race relations.

17. Ethnic minorities attended parties at majority white parties. ( )

18. A white administrator did not recommend a promotion for a qualified staff member of another race. ( )

19.An interracial couple was seen walking across campus.

20. When talking to a black student, a white faculty member used terms such as "boy". ( )

21.Students of all races participated in memorial programs for Dr. Martin Luther King. ()

22. A racial/ethnic minority applicant was denied admission to a social organization (Fraternity or Sorority). No reason for the decision was given. ( )

PART II

In this section, please describe how you feel about yourself. Circle one number for each of the following statements.

1.I feel that I'm a person of worth, at least on an equal basis with others.

$\begin{array}{cccc}\begin{array}{c}\text { Strongly } \\ \text { agree }\end{array} & \text { Agree } & \text { Disagree } & \begin{array}{c}\text { Strongly } \\ \text { disagree }\end{array} \\ 1 & 2 & 3 & 4\end{array}$


2. I feel that I have a number of good qualities.

$\begin{array}{cccc}\begin{array}{c}\text { Strongly } \\ \text { agree }\end{array} & \text { Agree } & \text { Disagree } & \begin{array}{c}\text { Strongly } \\ \text { disagree }\end{array} \\ 1 & 2 & 3 & 4\end{array}$

3. All in all, I am inclined to feel that I am a failure.

$\begin{array}{cccc}\begin{array}{c}\text { Strongly } \\ \text { agree }\end{array} & \text { Agree } & \text { Disagree } & \begin{array}{c}\text { Strongly } \\ \text { disagree }\end{array} \\ 1 & 2 & 3 & 4\end{array}$

4. I am able to do things as well as most other people.

$\begin{array}{cccc}\begin{array}{c}\text { Strongly } \\ \text { agree }\end{array} & \text { Agree } & \text { Disagree } & \begin{array}{c}\text { Strongly } \\ \text { disagree }\end{array} \\ 1 & 2 & 3 & 4\end{array}$

5. I feel I do not have much to proud of.

$\begin{array}{cccc}\begin{array}{c}\text { Strongly } \\ \text { agree }\end{array} & \text { Agree } & \text { Disagree } & \begin{array}{c}\text { Strongly } \\ \text { disagree }\end{array} \\ 1 & 2 & 3 & 4\end{array}$

6. I take a positive attitude toward myself.

$\begin{array}{cccc}\begin{array}{c}\text { Strongly } \\ \text { agree }\end{array} & \text { Agree } & \text { Disagree } & \begin{array}{c}\text { Strongly } \\ \text { disagree }\end{array} \\ 1 & 2 & 3 & 4\end{array}$

7. On the whole, I am satisfied with myself.

$\begin{array}{cccc}\begin{array}{c}\text { Strongly } \\ \text { agree }\end{array} & \text { Agree } & \text { Disagree } & \begin{array}{c}\text { Strongly } \\ \text { disagree }\end{array} \\ 1 & 2 & 3 & 4\end{array}$

8. I wish I could have more respect for myself.

$\begin{array}{cccc}\begin{array}{c}\text { Strongly } \\ \text { agree }\end{array} & \text { Agree } & \text { Disagree } & \begin{array}{c}\text { Strongly } \\ \text { disagree }\end{array} \\ 1 & 2 & 3 & 4\end{array}$

9. I certainly feel useless at times.

$\begin{array}{cccc}\begin{array}{c}\text { Strongly } \\ \text { agree }\end{array} & \text { Agree } & \text { Disagree } & \begin{array}{c}\text { Strongly } \\ \text { disagree }\end{array} \\ 1 & 2 & 3 & 4\end{array}$


Perceived Racism

10. At times I think I am no good at all.

$\begin{array}{cccc}\begin{array}{c}\text { Strongly } \\ \text { agree }\end{array} & \text { Agree } & \text { Disagree } & \begin{array}{c}\text { Strongly } \\ \text { disagree }\end{array} \\ 1 & 2 & 3 & 4\end{array}$

\section{PART III}

In this section, please circle the statement (either a or b) you agree with.

1. a. Children get into trouble because their parents punish them too much.

b. The trouble with most children nowadays is that their parents are too easy with them.

2. a. Many of the unhappy things in people's lives are partly due to bad luck.

b. People's misfortunes result from the mistakes they make.

3. a. One of the major reasons why we have wars is because people don't take enough interest in politics.

b. There will always be wars, no matter how hard people try to prevent them.

4. a. In the long run, people get the respect they deserve in this world.

b. Unfortunately, an individual's worth often passes unrecognized no matter how hard he tries.

5. a. The idea that teachers are unfair to students is nonsense.

b. Most students don't realize the extent to which their grades are influenced by accidental happenings.

6. a. Without the right breaks one cannot be an effective leader.

b. Capable people who fail to become leaders have not taken advantage of their opportunities. 
7. a. No matter how hard you try some people just don't like you.

b. People who can't get others to like them don't understand to get along with others.

8. a. Heredity plays the major role in determining one's personality.

b. It is one's experiences in life which determine what one is like.

9. a. I have often found that what is going to happen will happen.

b. Trusting to fate has never turned out as well for me as making a decision to take a definite course of action.

10. a. In the case of the well-prepared student, there is rarely if ever such a thing as an unfair test.

b. Many times exam questions tend to be so unrelated to course work that studying is really useless.

11. a. Becoming a success is a matter of hard work, luck has little or nothing to do with it.

b. Getting a good job depends mainly on being in the right place at the right time.

12. a. The average citizen can have an influence in government decisions.

b. This world is run by the few people in power, and there is not much the little guy can do about it.

13. a. When I make plans, I am almost certain that I can make them work.

b. It is not always wise to plan too far ahead because many things turn out to be a matter of good or bad fortune anyhow.

14. a. There are certain people who are just no good.

b. There is some good in everybody. 
15. a. In my case getting what I want has little or nothing to do with luck.

b. Many times we might just as well decide what to do by flipping a coin.

16. a. Who gets to be the boss often depends on who was lucky enough to be in the right place first.

b. Getting people to do the right thing depends upon ability, luck has little or nothing to do with it.

17. a. As far as world affairs are concerned, most of us are the victims of forces we can neither understand nor control.

b. By taking an active part in political and social affairs, the people can control world events.

18. a. Most people don't realize the extent to which their lives are controlled by accidental happenings.

b. There really is no such thing as "luck".

19. a. One should always be willing to admit mistakes.

b. It is usually best to cover up one's mistakes.

20. a. It is hard to know whether or not a person really likes you.

b. How many friends you have depends on how nice a person you are.

21. a. In the long run the bad things that happen to us are balanced by the good ones.

b. Most misfortunes are the result of lack of ability, ignorance, laziness, or all three.

22. a. With enough effort we can wipe out political corruption.

b. It is difficult for people to have much control over the things politicians do in office. 
23. a. Sometimes I can't understand how teachers arrive at the grades they give.

b. There is a direct connection between how hard I study and the grades I get.

24. a. A good leader expects people to decide for themselves what they should do.

b. A good leader makes it clear to everybody what their jobs are.

25. a. Many times I feel that I have little influence over the things that happen to me.

b. It is impossible for me to believe that chance or luck plays an important role in my life.

PART IV

For each item, please answer "T" for true or "F" for false.

1. In uncertain times, I usually expect the best. ( )

2. It's easy for me to relax. ( )

3. If something can go wrong for me, it will. ( )

4. I always look on the bright side of things. ( )

5. I'm always optimistic about my future. ( )

6. I enjoy my friends a lot. ( )

7. It's important for me to keep busy. ( )

8. I hardly ever expect things to go my way. ( )

9. Things never work out the way I want them to. ( ) 
10. I don't get upset too easily. ( )

11. I'm a believer in the idea that "every cloud has a silver lining". ( )

12. I rarely count on good things happening to me. ()

\section{PART V.}

In this last section, please tell us some things about yourself. This information will be used for statistical analysis only.

1. I am

$$
1 \text { female. } \quad 2=\text { male. }
$$

2. I am

$$
\begin{aligned}
& 1=\text { full-time PSU student. } \\
& 2=\text { part-time PSU student. }
\end{aligned}
$$

3. My racial/ethnic group is

$$
\begin{aligned}
& 1=\text { Native American or Alaskan Native } \\
& 2=\text { Asian-American or Pacific Islander. } \\
& 3=\text { Black/African American. } \\
& 4=\text { Hispanic/Latino American. } \\
& 5=\text { White/Caucasian. } \\
& 6=\text { Other (please specify }
\end{aligned}
$$

3. Age: years old. 